\title{
O golpe de 1964 e a instauração da ditadura civil-militar no Pará: apoios e resistências
}

\section{The coup of 1964 and the establishment of civil-military dictatorship in Pará: supports and resistances \\ Pere Petit e Jaime Cuéllar}

Em 1964, estávamos a 19 anos de distância do fim da ditadura do Estado Novo. E não fazíamos, nós estudantes, a menor idéia do que era um golpe militar, do que era uma ditadura e as terriveis consequências da supressão das liberdades democráticas, do medo, das perseguições, das prisões arbitrárias, das torturas, dos assassinatos políticos, do exilio de lideranças e talentos, da censura, do cerceamento da liberdade de ensino, das perdas incalculáveis em ciência e tecnologia e para a formação de uma inteligência nacional livre, corajosa e criadora.

Pedro Galvão, presidente da União Acadêmica Paraense de novembro de 1963 a abril de 1964

Pere Petit é doutor em História Econômica pela USP e professor da Faculdade de História da Universidade Federal do Pará (UFPA) (petitpere@ @otmail.com), e Jaime Cuéllar é mestrando em Comunicação, Linguagens e Cultura na Universidade da Amazônia e professor da Secretaria de Educação do Pará (Seduc-PA), (jcvelarde31@hotmail.com).

Artigo recebido em 31 de dezembro de 2011 e aprovado para publicação em 4 de abril de 2012. 


\section{Introdução}

Ainda que seja inegável o protagonismo da cúpula das Forças Armadas, sobretudo do Exército, no vitorioso golpe de estado iniciado no dia 31 de abril de 1964 e na posterior instauração e consolidação da ditadura civil-militar, a relativa facilidade da vitória dos militares golpistas seria impensável sem o apoio de amplos setores da sociedade civil liderados pelos políticos conservadores, empresários e fazendeiros, entre outros atores e instituições, pela maioria dos membros da hierarquia da Igreja Católica e pelos meios de comunicação de massa. Foram esses setores que alimentaram durante anos, sobretudo a partir de 1961, a luta contra os reformistas-populistas e contra a crescente influência na sociedade brasileira dos partidos e organizações de esquerda, especialmente o Partido Comunista Brasileiro (PCB). Tal constatação se impõe sem desmerecer, nunca, o apoio ideológico, econômico e militar do governo dos Estados Unidos aos golpistas no contexto internacional da Guerra Fria e do impacto no continente americano da Revolução Cubana e, portanto, da disputa político-ideológica entre partidários do sistema capitalista e socialista no mundo.

Estas páginas sintetizam os resultados e reflexões das pesquisas realizadas pelos autores sobre a ditadura civil-militar no Pará (1964-1985) e se alimentam, além de fontes oficiais e hemerográficas (jornais e revistas de Belém), de livros de memórias, artigos que examinam a produção historiográfica sobre o regime militar e entrevistas realizadas em 2011 com alguns líderes do movimento estudantil e dos partidos de esquerda no Pará em 1964.

Entre os livros de memórias destacamos o intitulado A Planície (1990), escrito pelo principal articulador do golpe de estado no Pará, o ex-governador e ex-ministro Jarbas Passarinho, ${ }^{1}$ e sobretudo 1964: relatos subversivos - os estudantes e o golpe militar no Pará (2004), no qual se recolhem os textos de oito pessoas que tiveram destacada participação no movimento estudantil paraense e que apresentam algumas das suas recordações e reflexões sobre os acontecimentos políticos ocorridos no Pará em 1964. A edição de mil livros, financiada pelos próprios autores, foi rapidamente consumida pelo público, ávido por novidades na produção sobre a ditadura civil-militar instalada no país 40 anos antes. Carlos Fico explicava, em 2004, que o crescente número de publicações, seminários e debates sobre o regime militar relaciona-se ao fato de que velhos mitos e estereótipos estão sendo superados, graças tanto à pesquisa histórica factual de perfil profissional quanto ao que poderíamos caracterizar como um "desprendimento político" que o distanciamento histórico possibilita: tabus e ícones da esquerda vão sendo contestados sem que tais críticas possam ser classificadas como "reacionárias". Ao mesmo tempo, também vão sendo abandonados clichês sobre o golpe de 64, os militares e o regime, como a ideia de que só após 1968 houve tortura e 
censura; a versão de que os oficiais-generais não tinham responsabilidade pela tortura e o assassinato político; a impressão de que as diversas instâncias da repressão formavam um todo homogêneo e articulado; a classificação simplista dos militares em "duros" ou "moderados" etc. Por tudo isso, podemos falar em uma nova fase da produção histórica sobre o período (Fico, 2004: 30).

Passados 27 anos do fim da ditadura civil-militar, o Brasil está, certamente, bem distante de medos de represálias típicos dos tempos de práticas ditatoriais. Hoje, as testemunhas daqueles anos emergem das "zonas de silêncio" (Pacheco, 2011) nas quais ficaram mergulhadas por força das circunstâncias. Entre memória e história existem entrelaçamentos e autonomias. Quanto à memória, sabemos todos da necessidade de contextualizá-la, de cotejá-la, de criticá-la, por sabê-la inexoravelmente seletiva, às vezes unilateral e, sempre, condicionada pelo momento no qual as falas são emitidas e os textos são escritos e retocados para serem feitos públicos. O que importa não é propriamente a correspondência entre a/s memória/s e o processo histórico que pretendemos "reconstruir" e "refletir", mas a lógica e a consistência interna das versões e informações fornecidas pelos indivíduos escolhidos como "material histórico", seja nas entrevistas, nos seus discursos ou nos seus textos autobiográficos, os quais nos fornecem verdades parciais que usamos como materiais para construir nossos textos após dialogar com nossas visões de mundo, subjetividades e pretensões de cientificidade.

\section{A “Revolução de 1964" no Pará}

No dia 31 de março, o general Olympio Mourão Filho, comandante da $4^{\mathrm{a}}$ Região Militar, sediada em Belo Horizonte, Minas Gerais, ordenou às tropas sob seu comando que se dirigissem ao Rio de Janeiro para exigir a renúncia do presidente João Goulart. Iniciava-se o vitorioso golpe de estado que instauraria a ditadura civil-militar que perduraria, em suas diferentes fases de governo, sempre controladas pelas Forças Armadas, até março de 1985, quando, pela primeira vez desde abril de 1964, um civil, José Sarney, assumiu a presidência da República.

Em Belém, no dia $1^{\circ}$ de abril, o general Orlando Ramagem, chefe do Comando Militar da Amazônia (CMA), se reunia com o tenente-coronel Jarbas Passarinho e os membros do Exército, Marinha e da Aeronáutica que integravam o CMA. Jarbas Passarinho foi quem intermediou a conversa por rádio-amador entre Ramagem e o QG do II Exército (São Paulo-Mato Grosso), sob comando do general Amaury Kruel, considerado um militar "legalista" como o general Ramagem. Pela manhã Ramagem ainda estava muito reticente em apoiar o golpe 
de estado, mas a partir da conversa com o general Kruel, considerado até aquele dia um dos homens de confiança do esquema militar do presidente Jango, por volta das 15 horas aderiu ao golpe.

A figura do general Orlando Ramagem [...] parecia uma incógnita para os líderes da conjura local. Ramagem era anticomunista e participara da Cruzada Democrática, grupo que se antagonizou a Estillac Leal e a Lott nas disputas dos anos 50 no Clube Militar. Mas nada indicava uma vocação golpista. Seu comportamento por isso foi expectante e aderente ao golpe depois de sua consumação (Barata, R. A., 2004: 281).

No dia $1^{\circ}$ de abril a maioria dos militares e governadores do país tinha aderido ao golpe. Não foi este o caso do governador do Amazonas e do interventor federal no Amapá, que tornaram pública sua oposição ao levante militar. O governador do Pará, Aurélio do Carmo, encontrava-se no Rio de Janeiro, e o vice-governador, Newton Miranda, relutava em manifestar publicamente o apoio aos golpistas, como fora sugerido pelo Estado-Maior do Comando Militar da Amazônia. Entretanto, já na noite daquele dia, o governador manifestou, em telegrama remetido a Belém, o apoio à "Revolução". Assim, como escreveu o cientista político paraense Amílcar Tupiassu: "Quando uma atitude foi explicitada, a situação no Centro-Sul do país já se definira - o governo paraense do [Partido Social Democrático] PSD/ [Partido Trabalhista Brasileiro] PTB optou pelos vitoriosos" (Tupiassu, 1968: 31).

Aurélio do Carmo também aceitou que seu nome fosse incluído entre os signatários do Manifesto ao Povo do Pará, através do qual autoridades civis e militares mostraram sua solidariedade ao movimento militar. Nos primeiros parágrafos do Manifesto, cuja redação foi encomendada pelo general Orlando Ramagem a Jarbas Passarinho, lia-se:

Não poderiam os paraenses, pelo seu governador, e os militares, por seus chefes legítimos, retardar por mais tempo a sua completa adesão ao abençoado movimento, que eclodiu no generoso solo de Minas Gerais [...], que logo se irradiou por todo o território pátrio. Tão pronto alguns problemas locais foram satisfatoriamente solucionados, como recomendava a virtude da prudência e o desejo do não derramamento de sangue dos amazônidas, Governo e Comandantes Militares, em íntima comunhão de pensamento, ligados pelo mesmo amor ao Brasil, e igualmente repudiando o comunismo ateu e tirânico, fazem saber à 
Nação brasileira a sua firme e inabalável determinação de formarem ao lado das forças que se batem pela restauração do princípio da autoridade e pelos fundamentos da própria organização militar, que são a disciplina e a hierarquia, tão vilmente vilipendiados e enxovalhados pela mais despudorada demagogia e pela deplorável ausência de espírito público (Passarinho, 1990: 105-106).

No dia 4 de abril, os jornais de Belém reproduziam uma nota oficial do presidente do PSD no Pará e prefeito de Belém, Moura Carvalho:

No momento em que a nação retorna à plenitude do seu regime democrático como resultado do esforço patriótico das nossas gloriosas Forças Armadas, o que representou a aspiração de todo povo brasileiro, desejo na qualidade de militar e com a responsabilidade de uma liderança partidária proclamar a incontida vibração de que me acho possuído por esse acontecimento histórico que significa o esmagamento definitivo da traição e dos inimigos da Pátria. Desde os primeiros instantes da crise coloquei-me ao lado daqueles que desejam devolver a tranquilidade e a paz ao nosso povo, dentro dos postulados constitucionais que fixaram como base da organização das Forças Armadas, o princípio da disciplina e da hierarquia. Acompanhei, aliás, nessa atitude, a posição lúcida assumida pelo governador Aurélio do Carmo, que não faltou nessa hora com sua palavra de fé no regime democrático e na defesa da Constituição (A Província do Pará, 4/4/1964).

Após seu retorno a Belém, o governador Aurélio do Carmo também apoiou a proposta de que o novo presidente da República fosse o general Castelo Branco. Vejamos, a seguir, o telegrama remetido por ele a Castelo Branco, no mesmo dia em que este foi escolhido, pelo Congresso Nacional, presidente da República:

Combatendo a inflação, criando condições essenciais à urgente reconstrução econômica, promovendo a regulamentação de nosso crédito externo, e restabelecendo as liberdades públicas, dentro das contingências impostas pelos últimos acontecimentos, a autoridade do novo presidente da República e suas normas traçadas de governo constituem uma segurança para todos os brasileiros. Começando com as esperanças gerais, em nome da coletividade que nos honrou com sua 
confiança nas urnas, congratulo-me com o Excelentíssimo Senhor General Humberto de Alencar Castelo Branco pelo período administrativo que hoje se inicia e formulo os mais veementes votos pela sua felicidade pessoal (A Província do Pará, 15/4/1964).

\section{Retornando ao passado para tentar compreender ... 1964}

No dia 29 de maio de 1959, morria em Belém uma das principais lideranças políticas do Pará no século XX: Magalhães Barata. Militar, tenentista, interventor federal entre 1930 e 1935 e entre 1943 e 1945, fundador no Pará do PSD, eleito senador em 1945 e governador em 1955. A máquina político-eleitoral criada por Magalhães Barata, que se sustentava no seu carisma, mas também nas relações clientelísticas com os comerciantes e grandes proprietários de terra que asseguravam ao PSD o controle de boa parte das prefeituras dos municípios do interior, obteve uma nova vitória em 1960, ao eleger o advogado Aurélio do Carmo governador.

Nas eleições de 1962, o PSD elegeu quatro dos dez deputados federais paraenses e 17 dos 37 membros da Assembleia Legislativa. Dos seis deputados estaduais eleitos pelo PTB em 1962, o advogado e escritor Benedito Monteiro foi quem maior número de votos obteve. Os comandantes do Estado-Maior do Comando Militar da Amazônia, acusando Monteiro de comunista e subversivo, tentaram impugnar sua eleição, mas suas alegações não foram aceitas pelo Tribunal Eleitoral, nem tampouco as que se voltavam contra o jornalista, líder do PCB e presidente do Sindicato dos Bancários de Pará e Amapá, Raimundo Jinkings, primeiro suplente na chapa do PTB-PSB para a Câmara Municipal de Belém.

O PCB, apesar das inúmeras cisões que sofreu na década de 1960, continuou sendo o principal partido de esquerda no país até a fundação do Partido dos Trabalhadores (PT). Fundado em 1922, o PCB obteve sua legalização em 1945, no fim do Estado Novo. Em janeiro 1948, num momento em que o mundo entrava em plena Guerra Fria, voltou à clandestinidade ao ter cancelado seu registro pelo Superior Tribunal Eleitoral (7 de maio de 1947) e serem cassados pelo Congresso Nacional (7 de janeiro de 1948) os mandatos de todos os seus representantes eleitos entre 1945 e 1947, entre eles o deputado estadual paraense Henrique Felipe Santiago.

Embora na ilegalidade, o PCB exerceu considerável influência na política nacional e no cenário político paraense até o golpe de estado de 1964, especialmente nos sindicatos urbanos e rurais, no movimento estudantil e no meio intelectual e artístico. Nesses anos militantes e militantes do PCB candidatavam-se a mandatos eletivos pelo PTB ou pelo Partido Socialista Brasileiro (PSB). O PCB 


\section{O golpe de 1964 e a instauração da ditadura civil-militar no Pará}

liderava no Pará, entre outros, os sindicatos dos estivadores, petroleiros e bancários.

Na primeira metade da década de 1960, o Partido Comunista do Brasil (PCdoB), a Ação Popular (AP), a Organização Revolucionária Marxista-Política Operária (ORM-Polop) e organizações trotskistas eram as principais forças políticas que, no espaço da esquerda, competiam com o PCB. De todas essas organizações, apenas AP dispunha de relativo peso político no Pará antes do golpe militar, ainda que a Polop também contasse com um pequeno grupo de simpatizantes em Belém.

A AP foi fundada em 1962 por membros de entidades ligadas à juventude católica, sobretudo à Juventude Universitária Católica (JUC) e à Juventude Estudantil Católica (JEC). Sua atuação no Pará centrou-se no movimento estudantil, em sindicatos de Belém e entre camponeses da microrregião Bragantina. Em Belém, militantes da AP lideravam o movimento dos estudantes secundaristas e o Sindicato dos Metalúrgicos e tinham bastante influência na União Acadêmica Paraense (UAP), entidade que reunia os diferentes Diretórios e Centros Acadêmicos da Universidade do Pará, cuja diretoria era compartilhada com o PCB e o grupo dos denominados independentes. Segundo o jurista Ronaldo Barata, liderança do movimento estudantil e militante do PCB em 1964:

Foi no seio da juventude universitária que a AP construiu o seu setor mais numeroso, afirmando-se como corrente forte capaz de eleger, em aliança com o PCB, três presidentes da União Nacional dos Estudantes - UNE: Aldo Arantes, Vinicius Brandt e José Serra. No Pará, a AP nasceu no período em que a UNE Volante se deslocou por todo o Brasil (Barata, R., 2004: 125-126).

Tentando resistir: sindicalistas, estudantes...

Diferentemente do governador, vice-governador e prefeitos do Pará, que não manifestaram nenhuma repulsa formal contra o levante militar, as lideranças locais tanto do Comando Geral dos Trabalhadores (CGT) e da União Acadêmica Paraense (UAP), como do PCB e da AP, tentaram organizar os trabalhadores e estudantes de Belém e de outros municípios paraenses para se contrapor aos golpistas. Com essa finalidade, ambas as entidades publicaram notas de repúdio e chamadas à mobilização. Vejamos, a seguir, o manifesto do CGT, e, posteriormente, da UAP, ambos reproduzidos, no dia $1^{\circ}$ de abril, no fornal do Dia e na Folha Vespertina. ${ }^{2}$ 


\section{Trabalhadores e estudantes unidos contra o golpe}

Os trabalhadores paraenses estão, desde ontem, em intensa manifestação. Todos os dispositivos de arregimentação acham-se em célere funcionamento, aglutinando forças que deverão entrar em ação a qualquer momento, em caso de ordem do CGT, que esta madrugada decretou greve geral. Para afirmar posição nesse sentido reuniram-se ontem a Federação dos Marítimos, os Sindicatos do Petróleo, Operários Navais e PUA. Hoje estarão reunidos os Estivadores, Náuticos, Arrumadores, Motoristas, Marítimos, Bancários, Alfaiates, telegráficos, além de outros. Um emissário deveria seguir hoje para o Rio, com missão especial, em face dos acontecimentos. A situação, assim, era de alerta.

\section{UAP: Nota Oficial}

A União Acadêmica Paraense, cumprindo decisão de seu Congresso Extraordinário ontem realizado, considerando que se desenvolve no país um processo golpista contra o mandato do Presidente da República, e atentando à orientação da União Nacional dos Estudantes, resolve: 1-Decretar greve geral dos universitários paraenses até que seja destruído todo o esquema golpista que ameaça o Brasil; 2 - Conclamar todos os oficiais, sargentos, soldados, trabalhadores, camponeses e o povo em geral para cerrarem fileiras em torno do Presidente da República, que encarna, neste momento, os sentimentos reformistas de libertação do povo brasileiro.

No dia $1^{\circ}$ de abril as aulas foram suspensas pelas autoridades, e muitos estudantes universitários e secundaristas se concentraram na sede da UAP, acompanhando a Vigília Cívica pela Democracia convocada pela UAP na sua sede na avenida São Jerônimo (hoje José Malcher). Lá, por meio de um alto-falante, irradiavam hinos patrióticos, canções libertárias e notícias das rádios legalistas, sobretudo do Rio Grande do Sul, estado no qual Leonel Brizola, como fizera em 1961, tentava organizar a defesa da legalidade e a permanência de João Goulart na Presidência da República.

$\mathrm{Na}$ tarde desse mesmo dia, o coronel José Lopes de Oliveira ("Peixe-agulha"), recebeu ordens de prender os "subversivos" que pudessem colocar em risco todo o aparato montado desde o Centro-Sul até Belém. À noite, a UAP foi invadida por indicação de Jarbas Passarinho e com reticências do general Orlando Ramagem, que foi voto vencido na aprovação dessa ação. O estudante do curso de Direito José Seráfico de Carvalho, ao tentar sair pela porta de entrada - enquanto todos corriam pela porta dos fundos - foi recebido com uma bofetada pelo coronel "Peixe-agulha"... 


\section{O golpe de 1964 e a instauração da ditadura civil-militar no Pará}

... de arma em punho, uma pistola na sua mão esquerda (...). Eles invadiram, e eu, me julgando mais esperto do que os colegas, ao invés de correr para trás, corri ao encontro dos militares para enquanto eles se preocupavam em entrar eu sair e tentar me escafeder. Fui recebido ou recebi o coronel, na entrada, com um bofetão no lado esquerdo do meu rosto, porque ele trazia a destra vazia, disponível para esse ato da democracia em que ele acreditava naquele momento, a democracia do bofete (José Seráfico de Carvalho, entrevista realizada em Belém em 9/10/2011).

Aquele gesto foi símbolo do destempero, afirma Pedro Galvão, que, ao ser indagado, em entrevista realizada em 25 de maio de 2011, sobre ter presenciado o gesto do agressor, respondeu que "não lembrava" de ter visto ou não. Entretanto, a cena teve tamanha repercussão que, em seu livro de memórias, descreveu aquela violência com tanta precisão que pareceu ter visto.

Todas as lideranças do movimento estudantil de Belém que escreveram seus relatos para o livro 1964 - relatos subversivos, e também as que foram entrevistadas em 2011, mencionaram o ataque à sede da UAP como o momento mais representativo da vitória dos golpistas no Pará e como um dos momentos mais traumáticos em suas vidas e na história do movimento estudantil paraense. $\mathrm{O}$ processo ditatorial no Pará, segundo as memórias dos então estudantes, parecia que não tinha mais volta.

Nas janelas da frente da UAP fomos surpreendidos pela chegada espaventosa da tropa, soldados avançando no marche-marche típico da ordem unida militar, deitando nas calçadas e no asfalto, onde posicionavam os tripés de suas metralhadoras apontadas contra nós. Daí para frente tudo foi correria e atropelo, a rapaziada escapando pelos fundos, galgando muros, varando os quintais vizinhos (...). Vi uma bandeira brasileira estraçalhada no assoalho, vi a turma de estudantes de braços erguidos contra as paredes no salão, vi a brutalidade irracional investindo contra cadeiras, mesas, armários, mimeógrafos, equipamentos de som. Não vi, e foi melhor não ver, o nosso teatrinho ser destroçado, o Teatro de Arte Popular, que construímos no quintal da sede (...). Vi o medo no ar (Galvão, 2004: 19-20).

O movimento universitário, o movimento estudantil, tinha acabado. A UAP havia sido invadida e depredada por uma tropa do Exército comandada pelo famoso coronel José Lopes de Oliveira, 
apelidado "Peixe-agulha", tido como do esquema militar do Jango imagina se não fosse! -, com manifestação popular de aplausos dos que apoiavam e da "maioria silenciosa" presente em frente da sede da UAP, no quarteirão da São Jerônimo, entre Rui Barbosa e Benjamim. Insuflados, dizem as boas e as más línguas, por alguns "lenços brancos" [...]; eu estava dentro e escapei [...]. Alguns colegas, surpreendidos dentro e fora da UAP, foram presos (Cortez, 2004: 53-54).

\section{A noite dos "Lenços brancos"}

Dias antes, convocados pela União Internacional dos Estudantes (UIE) e a UNE, com organização da UAP, haviam chegado a Belém estudantes de diferentes municípios paraenses e de outros estados brasileiros, estudantes argentinos, bolivianos, colombianos, guianenses, venezuelanos e peruanos e parte da diretoria da UNE, para participar do I Seminário Latino Americano de Reforma e Democratização do Ensino Superior (SLARDES).

Na noite de 30 de março, um dia antes do levante militar em Minas Gerais, a capital do Pará conheceria a violência das elites burguesas e dos militares golpistas. Jarbas Passarinho, estudantes de Belém e da ilha do Marajó e membros da Polícia Militar iniciaram sua denominada "Revolução" tentando impedir o ato de abertura do SLARDES, que estava sendo realizado no auditório da antiga Faculdade de Odontologia. A invasão deveria ter acontecido em sincronia com a ação da Polícia Militar, cuja incumbência seria agredir e prender aqueles que não tivessem lenços brancos amarrados no pescoço. Por alguma feliz razão, os "lenços brancos" invadiram o auditório antes do momento combinado com oficiais da PM:

Poderia ter sido uma carnificina, alguém me contou, talvez exagerando, alguns anos mais tarde. E só não o foi porque houve uma precipitação. Era para ser uma ação sincronizada entre os invasores, filhos de fazendeiros em sua maioria, e uma força da Polícia Militar do Estado. Por sorte, um daqueles rapazes [que fazia parte dos chamados "lenços brancos"], o Mickey Lobato, esporeado pelos nervos, detonou a invasão alguns minutos antes do tempo. A tropa só chegaria depois, quando já conseguiríamos serenar os ânimos. Mickey entrou berrando palavrões, interrompendo o discurso do representante da Nicarágua, se esta miserável memória não me trai (...), gritavam "vamos acabar com esta merda, bando de comunas filhos da puta” (Galvão, 2004: 21). 
Segundo o poeta e professor da UFPA João de Jesus Paes Loureiro:

Naquela noite lá na SLARDES nós fomos vítimas da agressão dos "lenços brancos". Que eram rapazes da chamada burguesia da época. Essa classe média alta. E com muitos filhos de fazendeiros do Marajó. E que criaram uma associação pra enfrentar os esquerdistas e pra serem identificados numa hora de briga ou qualquer coisa. Ou quando chegasse a polícia, com quem eles estavam mancomunados. A polícia sabia em quem deveria baixar a porrada e em quem não deveria. $\mathrm{Ou}$ quem devia prender. Então a identificação deles era o lenço branco amarrado no pescoço. E foi a primeira vez que ocorreu essa manifestação deles (entrevista realizada em Belém em 3/3/2011).

\section{Procurando e encarcerando os comunistas e seus aliados}

Nas semanas seguintes ao golpe de estado, centenas de militantes dos partidos de esquerda, algumas lideranças do PTB e PSD, sindicalistas, militares e estudantes progressistas foram presos, e muitas organizações e entidades sindicais, especialmente as Ligas Camponesas e os sindicatos vinculados ao CGT, foram declarados ilegais, dissolvidos ou colocados sob intervenção. No Pará, cerca de 300 pessoas foram detidas durante e após o $1^{\circ}$ de abril de 1964.

A maioria dos presos eram estudantes universitários, lideranças sindicais e militantes da AP e, sobretudo, do PCB. Os sindicatos sob influência do PCB também sofreram intervenção. Forças militares e policiais, apoiadas por grupos civis, invadiram no $1^{\circ}$ de abril as sedes, em Belém, do PTB, do Sindicato dos Petroleiros e da UAP.

Ficou sob a responsabilidade do futuro prefeito de Belém e governador do Pará, o major Alacid Nunes, ${ }^{3}$ interrogar aos "subversivos universitários". Jarbas Passarinho teve como principal objetivo localizar e prender aos membros do PCB.

Se buscavam comunistas, aquela noite tinha sido pródiga em bons resultados. Logo de cara prenderam duas importantes lideranças do PCB no Pará: Humberto Lopes, secretário político, e Jocelyn Brasil, coronel reformado da Aeronáutica [...]. No dia seguinte começaram as prisões em massa (Barata, R. A., 2004: 301). 
Pedro Galvão nos relata a sua detenção no dia $1^{\circ}$ de abril:

Aí eles me levaram para aquela camionete (...), era uma Rural Willis, eu acho, e fiquei sozinho ali alguns minutos (...), até o momento que eu vi ao longe (...) dois homens em cuecas e escoltados por uns soldados. Eram o Jocelyn Brasil e o Humberto Lopes. Eles foram colocados do meu lado, na Rural Willis. E depois de algum tempo nos levaram numa longa volta pela cidade. Um comboio feito por aquela camionete e outros, passando por vários bairros como se eles quisessem nos mostrar, que estavam prendendo (...). Depois nos levaram para o Quartel General na Praça da Bandeira (...), e ali encontrei a representação mesmo do poder. Estavam lá dentro (...) comandantes do Exército, da Aeronáutica e da Marinha. E alguns áulicos: Jarbas Passarinho, comandante do Estado Maior, da $2^{\text {a }}$ Seção ou coisa assim, do Exército aqui em Belém. $\mathrm{O}$ vice-governador, que era apelidado de "Cococa", não me lembro qual primeiro nome dele, mas o apelido dele era "Cococa". E era um direitista... Me parecia um áulico. Se podia usar essa impressão: bajulando os golpistas, os oficiais que estavam acompanhando o golpe (entrevista realizada em Belém em 25/5/2011).

Também foram presos o presidente do Sindicato dos Petroleiros, Carlos Sá Pereira, e o ex-deputado federal Ruy Barata, ambos do PCB. O deputado estadual Benedito Monteiro (PCB) conseguiu fugir de Belém, mas foi preso no município de Alenquer em meados de abril. Benedito Pereira Serra, presidente da União dos Lavradores da Zona Bragantina, detido no município de Castanhal, morreu no Hospital Militar de Belém no dia 16 de maio de 1964, sendo registrada como causa de seu falecimento hepatite aguda. Pedro Galvão, presidente da UAP, detido, como vimos acima, após a invasão da sede da UAP, foi inicialmente liberado, mas seria novamente preso após ser aberto contra ele Inquérito Policial Militar. No final de junho de 1964 os presos políticos do Pará foram postos em liberdade.

\section{Jornais, fazendeiros e Igreja Católica: o velho e o novo bloco no poder}

Destaque especial contra as reformas democrático-progressistas e contra o "comunismo" tiveram os jornais, rádios e canais de TV, antes, durante e após o golpe de estado. No caso da imprensa paraense, os discursos jornalísticos acabaram solidificando opiniões, desvelando outras, mas, acima de tudo, produ- 
ziram discussões, confrontos e um sem número de imagens acerca do que fosse o perigo comunista ou a ameaça vermelha para a sociedade brasileira. Tratava-se de matérias que "desqualificavam" o ideário marxista como estratégia de embate ideológico que permeou a Guerra Fria. Os artigos versavam sobre o "Perigo Vermelho", "Cubanização", "Avanço Comunista" e outras expressões que instigavam os leitores a pensar esse regime sócio-político-econômico como um inimigo a ser combatido (Velarde, 2005; Sousa, 2011).

Os jornais a Folha do Norte e A Província do Pará foram os que mais se destacaram em Belém nessa empreitada. Jarbas Passarinho afirma que era ele quem escrevia todos os editoriais do jornal A Província do Pará "na linha de oposição severa ao que se passava no Brasil” (Passarinho, 1990: 85). Segundo Ruy Antonio Barata, para os editorialistas de direita dos jornais do Pará,

todos aqueles que se alinhassem ao lado das reformas de base (agrária, sanitária, bancária, universitária) eram automaticamente rotulados de comunistas. Ao debate sobre as grandes nacionais, preferiam a forma tosca, mas historicamente eficaz: a satanização dos comunistas, como impositivo estratégico para o sucesso do golpe militar, anteriormente desarmado na renúncia de Jânio Quadros, em agosto de 1961, e reduzido a um punhal parado no ar com o suicídio de Vargas em agosto de 1954 (Barata, R. A., 2004: 277).

Jornais de Belém também colaboraram com os golpistas na "caça aos comunistas":

$\mathrm{O}$ anonimato da denúncia política e ideológica era incentivado e premiado. O "informante invisível", famosa coluna do fim de semana da Folha do Norte, divulgava listas dos suspeitos recomendando as suas prisões. $\mathrm{O}$ "dedo duro" virava uma instituição política nacional, cultivada com requinte [...]. A direita estava eufórica e sorridente [...]. Alguns colegas estavam presos, outros foragidos, e uns talvez até pirando. Ninguém se sentia seguro. A repressão estava apenas começando. Ela iria a endurecer... (Cortez, 2004: 55-56).

Personagem de inestimável relevância na "luta contra o comunismo" no Pará foi Dom Alberto Ramos, arcebispo de Belém, sobretudo através de artigos publicados no jornal católico a Voz de Nazaré. Na sua visita ao jornal A Província do Pará, 
Dom Alberto parabenizou $A$ Província pela vitória da causa da Democracia no país, pela qual muito nos batemos sem temores nem desfalecimento fieis às tradições de liberdade do nosso povo, de cujo coração Cristo não desertou, nem foi, como nunca será afastado $(A$ Província do Pará. Belém, 4/4 /1964).

Dom Alberto Ramos, além de declarar seu apoio ao levante militar, não fez qualquer gestão em favor dos padres e estudantes católicos que foram presos naqueles dias, a maioria deles membros da AP e das JUC (Coimbra, 2003). Também estimulou a convocatória da Marcha com Deus pela Família, liderada pelas senhoras das frações conservadoras do catolicismo, a Cooperativa de Fazendeiros do Marajó e diretores da Assembleia Paraense, "que logo seriam aquinhoados com cargos pelos relevantes serviços prestados à redenção do país” (Barata, R. A., 2004: 298).

\section{Os militares afastam os civis e assumem o governo do Pará e a prefeitura de} Belém

No dia 21 de maio de 1964, iniciaram-se os trabalhos da Comissão de Investigação Sumária (CIS), integrada por oficiais das três Forças Armadas e presidida pelo general Bandeira Coelho, então interventor na Superintendência do Plano de Valorização Econômica da Amazônia (Spvea), com o objetivo de apurar as denúncias de corrupção e malversação de fundos públicos por parte dos membros do governo estadual e da prefeitura de Belém. No início de junho, a CIS apresentou seu relatório final, no qual os principais responsáveis pelo governo estadual e pela prefeitura de Belém e líderes do PSD eram acusados de suborno, malversação da coisa pública, clientelismo, inclusão de funcionários inexistentes na folha de pagamentos e recebimento de vultosas quantias derivadas do jogo do bicho.

As apurações da CIS não se restringiram ao uso indevido de dinheiro público ou corrupção, mas visaram também as atividades políticas dos membros do governo estadual e prefeituras paraenses. Assim é que nesse mesmo relatório da CIS, os responsáveis pela Secretaria de Educação e Cultura do governo do Pará foram acusados de "ter permitido, por omissão, a infiltração comunista na União de Estudantes dos Cursos Secundários do Pará, existindo 30, dos 38 diretórios estudantis secundários, com sinais de infiltração comunista" (Relatório da Comissão de Investigação Sumária, A Província do Pará, 18/6/1964).

Em 9 de junho de 1964, o governador e vice-governador do Pará, Aurélio do Carmo e Newton Miranda, respectivamente, e o prefeito e vice-prefeito de 
Belém, Moura Carvalho e Isaac Soares, tiveram seus mandatos cassados e seus direitos políticos suspensos por um período de dez anos. Também tiveram seus mandatos cassados, sob as mesmas acusações, Alberto Nunes (PTB), vereador de Belém; Agenor Moreira(PSD), prefeito de Cametá; e, entre outros, os deputados estaduais Amílcar Moreira (PSD), José Manuel Reis Ferreira (PSD) e Nagib Mutran, da União Democrática Nacional (UDN). Por estritas motivações políticas tiveram seus direitos políticos suspensos e mandatos eletivos cassados os militantes do PCB Raimundo Jinkings, vereador de Belém, e o deputado estadual Benedito Monteiro ("Dez paraenses na lista de ontem de cassação de mandatos e direitos”, A Província do Pará, 10/6/1964).

No seu livro A Planície, Jarbas Passarinho afirma que a cassação desses mandatos foi decorrente da apuração das denúncias de corrupção feitas contra os acusados. Contudo, como ele mesmo relata, a deposição dos principais responsáveis pelo governo estadual e pela prefeitura de Belém foi uma decisão tomada pela cúpula das Forças Armadas antes de serem iniciados os trabalhos da CIS (Passarinho, 1990: 110-111). A decisão foi favorecida pelo afastamento de Orlando Ramagem do Comando Militar da Amazônia, general que "não inspirava confiança aos chefes revolucionários" (idem: 111), substituído no início de junho pelo o general Bizarria Mamede. Portanto, ainda que Jarbas Passarinho assinale que tentou preservar o governador, ele próprio escreve que o "destino do Dr. Aurélio já estava, porém, a essa altura decidido em Brasília" (idem). Isso fica mais claro ainda quando assinala que o general Bizarria Mamede, "tão pronto chegou a Belém, mandou chamar-me à residência particular. Na ocasião, foi muito claro: 'a Revolução decidira intervir no Pará, como já o fizera no Amazonas, e a solução para o governo passava necessariamente por mim"' (idem).

As declarações do prefeito de Belém e do governador em apoio à "Revolução" não levaram aos militares golpistas a esquecer o apoio de ambas as lideranças do PSD às denominadas Reformas de Base preconizadas pelo governo de João Goulart e às mudanças no sistema político brasileiro, incluindo, por exemplo, a legalização do PCB, manifestado publicamente em diferentes ocasiões. Numa entrevista concedida ao jornal $A$ Província do Pará, no dia 5 de março de 1964, ao ser perguntado sobre a legalização do PCB, Aurélio do Carmo declarou ser "favorável, sob a justificativa de que, no regime democrático, todas as associações políticas devem ter seus direitos garantidos". Ao respeito da reforma agrária, afirmou que "toda reforma que vier em benefício do povo receberá sua opinião favorável [...]. Se a Supra quer mesmo fazer a reforma agrária, que o faça dentro dos processos de técnica da agricultura, dando assistência ao homem do campo".

No dia 12 de junho de 1964, a Assembleia Legislativa Paraense escolheu como governador, por unanimidade, o tenente-coronel Jarbas Gonçalves Passa- 
rinho e, como vice-governador, o empresário Agostinho Monteiro, que em 1946 fora eleito deputado federal na legenda da UDN, e em 1958 se candidatara ao Senado com o apoio do então governador Magalhães Barata e não fora eleito.

Também em junho de 1964, os vereadores de Belém elegeram o tenente-coronel Alacid Nunes como prefeito. Ao perder o PSD o controle do governo estadual e a prefeitura da capital, ficou facilitada a tarefa dos seus tradicionais e novos opositores, militares e outras pessoas sintonizadas com os golpistas de 1964, de liquidar a máquina político-eleitoral pessedista.

\section{Eleições de 1965 e nascimento do bipartidarismo}

Nas eleições para governador realizadas no dia 3 de outubro de 1965, o candidato dos partidários da "Revolução" no Pará foi Alacid Nunes. O candidato escolhido pelo PSD foi, curiosamente, o principal oponente eleitoral dos baratistas, o ex-governador e então senador, general Zacarias de Assumpção. A escolha era justificada pelas lideranças do PSD com o argumento de que somente um militar com notável respaldo eleitoral no Pará poderia tentar pôr freio à crescente influência política dos militares e civis vinculados a Jarbas Passarinho e Alacid Nunes. Este último, com o apoio do governador e da coligação de partidos integrada pela UDN, o PTB, o Partido Democrata Cristão (PDC) e o Partido Republicano (PR), venceu o pleito eleitoral sem muitas dificuldades somando um total de 163.527 votos contra 67.166 obtidos por Zacarias de Assumpção. Somente em cinco municípios, dos 83 então existentes no Pará, Assumpção foi o mais votado.

Num primeiro momento, diferentemente da maioria dos regimes militares instaurados nos países latino-americanos nas décadas de 1960 e 1970, a cúpula das Forças Armadas manteve inalterado o sistema eleitoral e partidista surgido no Brasil após a extinção do Estado Novo. Contudo, poucos dias depois da vitória dos candidatos do PSD aos governos estaduais de Minas Gerais e Guanabara, através do Ato Institucional n ${ }^{\circ}$, de 27 de outubro de 1965, todos os partidos foram declarados extintos e foram suspensas as futuras eleições diretas para presidente da República. Um mês depois, com o intuito de fornecer certa aparência democrática à ditadura civil-militar, foi instaurado o sistema bipartidarista, outorgando à Aliança Renovadora Nacional (Arena) o papel de aliado do regime e ao Movimento Democrático Brasileiro (MDB) o de "oposição". Aqueles que haviam sofrido a suspensão de seus direitos políticos não poderiam filiar-se nem a um partido nem a outro, ficando, portanto, impossibilitados de candidatar-se a qualquer cargo político-eletivo.

Ao ser instituído o bipartidarismo, a antiga disputa entre os membros do PSD e os da maioria dos restantes partidos existentes no Pará transferiu-se, 
em linhas gerais, para a oposição entre Arena, "forte, vitoriosa e em expansão", e o MDB, "fraco e pessimista" (Tupiassu, 1968: 38). Na Arena ingressaram, além de Jarbas Passarinho e Alacid Nunes, a grande maioria dos integrantes dos partidos que apoiaram a candidatura de Alacid Nunes, também Zacarias de Assumpção e muitas lideranças e militantes do PSD dos municípios do interior. A maioria das lideranças e militantes do PSD de Belém ingressou no MDB.

Nas eleições de 1966, Jarbas Passarinho, candidato a senador pela Arena, obteve 204.913 votos, enquanto Moura Palha, pelo MDB, recebeu apenas 40.078 votos. A Arena elegeu 8 dos 10 deputados federais a que o Pará tinha direito e 33 dos 41 deputados estaduais. Assim, como acertadamente ponderou Amílcar Tupiassu, na segunda metade da década de 1960, a vida política no Pará parecia ser decorrente mais de um sistema de partido único que de um sistema bipartidarista (idem: 62).

Em 1978, o ex-governador e então deputado federal Alacid Nunes seria indicado por Ernesto Geisel, por solicitação do marechal Cordeiro de Farias, para assumir seu segundo mandato de governador, em detrimento de Jarbas Passarinho, que também pretendia o cargo. Depois de extinto, em 1979, o sistema bipartidarista, Jarbas Passarinho, como a maioria dos membros da Arena, ingressaria no PDS. O então governador Alacid Nunes optou inicialmente por filiar-se ao PDS, mas depois liderou a recriação do PTB no Pará e, nas eleições de 1982, apoiou a candidatura vitoriosa de Jader Barbalho (PMDB) a governador.

Jarbas Passarinho e Alacid Nunes, disputando entre si o controle do partido no poder (Arena), converteram-se, a partir de 1964 até o início dos anos 1980, nas principais lideranças políticas paraenses, e preocuparam-se, em sua ação de governo, mais propriamente em implementar as diretrizes da "Revolução" do que em favorecer os interesses dos diferentes grupos ou classes sociais paraenses.

\section{Para concluir... sobre a ditadura civil e militar}

O engenheiro paraense Fernando José de Leão Guilhon assumiu o cargo de governador no dia 15 de março de 1971, sendo o primeiro civil, após a destituição de Aurélio do Carmo em 1964, que exerceu essa responsabilidade no Pará. Ainda que o vice-governador fosse um militar, o coronel Newton Burlamaqui Barreira, dos 30 cargos de maior responsabilidade do governo de Fernando Guilhon, apenas seis foram assumidos por membros das Forças Armadas. ${ }^{4}$ Outro ci-

vil, Aloysio da Costa Chaves, ex-reitor da Universidade Federal do Pará e ex-juiz do trabalho, também assumiu, em 1975, o cargo de governador. Dois anos de- 
pois, apenas quatro militares participavam do primeiro escalão do seu governo: o chefe do Gabinete Militar, o comandante da Secretaria de Estado de Segurança Pública, o responsável pelo Instituto de Terras do Pará (Iterpa) e o diretor-presidente da Cia. Paraense de Abastecimento. ${ }^{5}$ Sirvam esses exemplos para reforçar a importância da participação de setores da "sociedade civil" na consolidação da ditadura civil-militar no Pará.

Compartilhando as reflexões de Carlos Fico, para quem, "se a preparação do golpe foi de fato 'civil-militar', no golpe, propriamente, sobressaiu o papel dos militares" (Fico, 2004: 52), tentamos mostrar neste estudo de história local estadual (Belém-Pará) a hegemonia exercida pelos membros do Exército e, em menor medida, de outros setores das Forças Armadas no vitorioso golpe de estado de 1964 e no controle político direto ou indireto das instituições do estado brasileiro durante a vigência do regime militar. Contudo, ao destacar também a importância da participação de diferentes setores da "sociedade civil" no levante militar de 1964 e na consolidação e durabilidade do regime militar até 1985, em suas diferentes fases de governo, preferimos denominar esse período, seguindo a Daniel Araão Reis, ditadura civil-militar, ainda que não concordemos com a periodização (1964-1979) proposta por esse autor.

Tornou-se um lugar comum chamar o regime político existente entre 1964 e 1979 de "ditadura militar". Trata-se de um exercício de memória, que se mantém graças a diferentes interesses, a hábitos adquiridos e à preguiça intelectual. $\mathrm{O}$ problema é que esta memória não contribui para a compreensão da história recente do país e da ditadura em particular. É inútil esconder a participação de amplos segmentos da população no golpe que instaurou a ditadura, em 1964. É como tapar o sol com a peneira (...). Não, não se trata de esclarecer um equívoco. Mas de desvendar uma interessada memória e suas bases de sustentação. São interessados na memória atual as lideranças e entidades civis que apoiaram a ditadura. Se ela foi "apenas" militar ... (...). Desaparecem os civis que se beneficiaram do regime ditatorial. Os que financiaram a máquina repressiva. Os que celebraram os atos de exceção. O mesmo se pode dizer dos segmentos sociais que, em algum momento, apoiaram a ditadura (Reis, 2012). 
1. Jarbas Gonçalves Passarinho nasceu no dia 11 de janeiro de 1920 em Xapuri (Acre). Passou a maior parte da infância em Belém e ingressou na Escola de Cadetes em 1939. Eleito governador do Pará em junho de 1964, exerceu o cargo até janeiro de 1966. Foi também ministro de Trabalho e Previdência Social (governo Costa e Silva), da Educação (governo Médici), da Previdência e Assistência Social (governo João Figueiredo) e da Justiça (governo Collor).

2. O jornal a Folha Vespertina foi fundado em 1941, em Belém, pelo jornalista João Paulo Maranhão, como segundo jornal do grupo Folha do Norte, grupo editorial que encerrou suas atividades em 1974 ao ser comprado pelo Grupo Maiorana, dono do jornal O Liberal. Ofornal do Dia, vinculado

\section{Referências bibliográficas}

BARATA, Ronaldo. Cem dias quarenta anos depois. In: NUNES, André Costa et al. 1964 - Relatos Subversivos: os estudantes e golpe no Pará. Belém: Edição dos Autores, 2004, p. 119-149.

BARATA, Ruy Antonio. História de raça e pirraça nas terras do Grão Pará. In: NUNES, André Costa et al. 1964 - Relatos Subversivos: os estudantes e golpe no Pará. Belém: Edição dos Autores, 2004, pp. 269-307.

COIMBRA, Oswaldo. Dom Alberto Ramos mandou prender seus padres: a denúncia de politicamente aos petebistas (PTB), circulou em Belém entre 1961 e 1965.

3. Alacid da Silva Nunes nasceu em Belém no dia 25 de novembro de 1924. Ingressou na Academia Militar das Agulhas Negras (Rio de Janeiro) em 1946. Em 1960 foi secretário de Segurança do Território Federal do Amapá e, em 1961, governador interino do Amapá. Após a renúncia de Jânio Quadros retornou à vida militar.

4. Cf. Alacid Nunes, Mensagem à Assembleia Legislativa - 15 de julho de 1967; e Fernando Guilhon, Mensagem do Governador à Assembleia Legislativa do Pará - 31 de março de 1971.

5. Cf. Aloysio Chaves, Mensagem à Assembleia Legislativa do Pará - 31 de março de 1977.

Frei Betto contra o Arcebispo do Pará em 1964. Belém: Paka-Tatu, 2003.

CORTEZ, Roberto. 1964: quem conta um conto aumenta um ponto. In: NUNES, André Costa et al. 1964 - Relatos Subversivos: os estudantes e golpe no Pará. Belém: Edição dos Autores, 2004, p. 43-118.

DELGADO, Lucilia de Almeida Neves. 1964: temporalidade e interpretações. In: REIS, Daniel Aarão, RIDENTI, Marcelo \& MOTTA, Rodrigo Patto Sá (orgs.). O golpe 
militar e a ditadura: quarenta anos depois. Bauru: Edusc, 2004, p. 15-28.

FICO, Carlos. Algumas notas sobre historiografia e história da ditadura militar. Estudos de História, Franca, Unesp, vol. 8, $\mathrm{n}^{\circ}$ 1, 2001, p. 69-90.

Versões e controvérsias sobre 1964 e a ditadura militar. Revista Brasileira de História, São Paulo, vol. 24, nº 47, 2004, p. 29-60.

GALVÃO, Pedro. Vencidos e vencedores. In: NUNES, André Costa et al. 1964 Relatos Subversivos: os estudantes e golpe no Pará. Belém: Edição dos Autores, 2004, pp. 15-42.

PACHECO, Agenor Sarraf. Imagens narradas, memórias e patrimônios desvelados. Ensaio Geral, vol. 3, no 5, jan-jul/2011, p. 135-55.

PASSARINHO, Jarbas. Na planície. Belém: CEJUP, 1990.

PETIT, Pere. Chão de promessas: elites políticas e transformações econômicas no Es- tado do Pará pós-1964. Belém: Paka-Tatu, 2003.

REIS, Daniel Aarão. Ditadura, anistia e reconciliação. Estudos Históricos, Rio de Janeiro, vol. 23, $\mathrm{n}^{\mathrm{o}} 45$, jan-jun 2010, p. 171186.

A ditadura civil-militar. $O$ Globo, Rio de Janeiro, 31 de março de 2012.

SOUSA, Alaide Roberth Mendes de. $O$ golpe civil-militar e a importância dos jornais $A$ Província do Pará e O Liberal na sua trajetória e legitimação. Monografia de graduação em História (UFPA). Belém, 2011.

TUPIASSU, Amílcar. As eleições paraenses de 1966. Revista Brasileira de Estudos Políticos, Belo Horizonte, UFMG, $\mathrm{n}^{\circ}$ 23-24, 1968, p. 23-64.

VELARDE, Jaime Cuéllar. O vermelho nas letras de jornais: uma análise dos discursos anticomunistas na imprensa paraense (1961-64). Monografia de Conclusão de Curso de Especialização em Ensino de História do Brasil. Belém: IDEPA, 2005.

\section{Resumo}

Este artigo, inserido nos debates historiográficos sobre a ditadura civil-militar no Brasil (1964-1985), pretende contribuir para o conhecimento da história política do estado do Pará antes, durante e após o golpe de estado de 1964. Examinamos preferencialmente a participação dos militares e o apoio de setores da sociedade civil ao golpe militar, e a repressão que sofreram os estudantes e organizações de esquerda e políticos "populistas". Na perspectiva metodológica dos estudos de história local e regional, as principais fontes utilizadas foram os jornais de Belém, livros de memórias, trabalhos acadêmicos e fontes orais.

Palavras-chave: ditadura civil-militar; história política do estado do Pará; militares; movimento estudantil; partidos de esquerda; repressão política. 


\begin{abstract}
This article, inserted in the historiographical debates about the civil-military dictatorship in Brazil (1964-1985), intends to contribute to the knowledge of political history of the state of Pará before, during and after the coup of 1964. It preferably examines the participation of military forces and the support of civil society sectors to the military coup, and the repression suffered by the students, left-wing organizations and "populist" politicians. In the view of methodological studies of local and regional history, the main sources used were the newspapers of Belem, memoirs books, academic works and oral sources.
\end{abstract}

Key words: civil-military dictatorship; political history of the state of Pará; military forces; student movements; leftist parties; political repression.

\title{
Résumé
}

Cet article, inscrit dans les débats historiographiques sur la dictature civil-militaire au Brésil (1964-1985), veut contribuer à la connaissance de la conjoncture politique de l'état du Pará avant, durant et après le coup d'état de 1964. On analyse plus spécialement la participation des militaires et l'appui de secteurs de la société civile au coup d'état militaire, et la répression subie par les étudiants, les organisations de gauche et les hommes politiques 'populistes'. Dans la perspective méthodologique des études d'histoire locale et régionale, les principales sources utilisées ont été les journaux de Belém, les livres de mémoire, les travaux universitaires et les témoignages oraux. Mots-clés: dictature civil-militaire; histoire politique de l'état du Pará; militaires; mouvement étudiant; partis de gauche; répression politique. 